\title{
Globalisation and Learning
}

\author{
H.E. Msgr. Marcelo Sánchez Sorondo \\ Chancellor of the Pontifical Academy of Social Sciences \\ Casina Pio IV \\ V-00120 Vatican City \\ Tel: 390669881441 \\ Fax: 390669885218 \\ E-mail: vati332@acdscience.va
}

Website: http://www.vatican.va/roman_curia/pontifical_academies/acdscien/index_social_en.htm

Keywords: globalisation, education, justice, ethics, synthesize knowledge.

\section{THE PHENOMENON OF GLOBALISATION}

The human family has acquired a new awareness of its unity, integration and global interdependence. Globalisation is the defining characteristic of our time (Khor, 2000). Time and space are shrinking and many borders are disappearing, giving rise to an increasing interdependence between climates, environments, ecosystems, lives, economies, well-being (freedom from disease), cultures, religions and people. This 'New World Order', which emerged fully after 1989 with the collapse of European communism, is a dynamic and dialectic process whose characteristics have not been identified completely but one which has brought with it a belief in: ecological emergency; lower trade barriers; an end to exchange controls; a freer movement of investment capital, goods and people; new forms of labour; and the displacement of public sector capital by the private sector. This latest historical stage has created new possibilities and opportunities, and raised new hopes for the world, especially for developing countries. In fact, technological innovations (especially information technology, telematics, the global satellite network and the Internet), the new forms of labour, expanding trade and increased direct foreign investment offer enormous potential for the elimination of poverty, hunger, disease and illiteracy during the millennium that has just started (UNDP, 1999). Nevertheless, many of these potential benefits have not been realised so far for everyone and for the common good. Globalisation has been driven by the expansion of markets and financial systems not necessarily linked to production, leading to increasing levels of inequality in labour, income, resources, opportunities and especially in education. According to the latest 'Human Development Report', (UNDP, 2003) globalisation in this phase has benefited only one fifth of the world's population while marginalising the rest. Therefore, we cannot but agree with what the United Nations Millennium Declaration says: "We believe that the central challenge we face today is to ensure that globalisation becomes a positive force for the entire world's people". This is all the more evident after the atrocious terrorist act of 11 September 2001 and its direct consequences.

\section{FOR A GLOBALISATION WHICH INCLUDES REDISTRIBUTION}

In a certain sense, it seems that the world is now going through an experimental, dynamic but chaotic stage. The collapse of Eastern European Communism brought about the triumph of capitalism, but the latter is also a sick system. Today we can criticise capitalism from within without necessarily being accused of being PhiloCommunists. A market economy is the only system capable of producing enormous wealth. At the same time, however, it is the market economy itself that is responsible for causing massive levels of inequality and injustice, not least at a global level. Thus, a system combining both market laws and state intervention is needed. A free market presupposes non-intervention; justice, on the other hand, requires intervention. At the international level the issue that arises is how to govern globalisation. Or rather, in other words, according to the abovementioned 'Millennium Declaration', what can be done to extend the benefits of globalisation to everyone or, at the very least, to the majority of people: globalisation for all, a model for all. We are aware that there is more than one way to try to achieve this. Indeed, we suspect that it will be difficult for the developing world to embark on a journey based on the US model, but the same can be said for Europe. What must be done is to achieve at the international level a form of redistribution such as the one that states implement even if badly within their borders. There is no international body today that manages this redistribution. If redistribution within each state is difficult, it is all the more so at the international level where the problem has not even been properly taken into consideration. The seventies were all about development and developmentalism, and institutions were set up for this reason, such as the World Bank (1944) and the Inter-American Development Bank (1959), but no one since has focused on international redistribution, that is, 
on doing justice in a world which is ever more globalised.

Aware of the progressive disparity and inequality, in order to eradicate extreme poverty, hunger and illiteracy in the world, the rich nations have committed themselves to providing forms of aid which, although sporadic and relative, are a way to begin doing justice which we hope will increase and become more and more adequate. This commitment indicates a change, albeit an insufficient one. Between 1990 and 2001 official development aid went down from 0.33 percent to 0.22 percent of the GDP of the donor countries. On a positive note, however, last year the prolonged decline in official aid flows finally ended, reaching 57,000 million dollars (against 52,300 million in 2001). During the Conference on Financing for Development held in Monterrey in 2002, both the rich and the poor countries committed themselves to support the political reforms and the new resources necessary to reach the Millennium Development Goals, including the promise by the rich countries to give 0.7 of their GDP to public aid for development (PAD) and to increase by 16,000 million dollars the annual aid flows within the year 2006. However, even if the commitments announced in Monterrey were fulfilled, total aid would continue to be very far from the minimum figure of 100,000 million dollars needed each year, according to the recent 'Report on Human Development 2003'. In fact, fifty thousand million dollars are still lacking. If things remain as they are, "the fight against poverty is one hundred years away from fulfilling its goals and promises" as predicted by Gordon Brown, the British Chancellor of the Exchequer, who added: "the richest countries cannot continue to establish goals without fulfilling them systematically and hoping that the poorest countries calmly continue to believe in us" (Le Figaro économique, 2004). In a world which is ever more globalised, actions within national borders are not sufficient and international cooperation is necessary for the common good. For the rich countries fulfilling their commitments is an ethical issue. This is not benevolence but justice; justice is, as we shall see, the main virtue of a policy aimed at achieving the common good.

\section{JUSTICE IS THE WAY TO PEACE AND SOCIAL GOOD}

I very much bear in mind the declaration of the Supreme Pontiff, the first Polish Pope in history, to the effect that "Peace is born not only from the elimination of theatres of war. Even if all these latter were eliminated others would inevitably appear, if injustice and oppression continue to govern the world. Peace is born of justice: Opus iustitiae pax" (The Pontifical Academy of Sciences, 2003). Just as one can say that all research should be directed towards truth, so human society, to be truly human, cannot but have another goal, that of justice. Thus, social good passes through justice ${ }^{1}$. In a realistic climate, St Thomas Aquinas affirms that the attraction towards good and towards a just relationship with other people, has priority over all the other figures of conscience and is the beginning of the ethical dimension: "man has a natural inclination to know the truth about God, and to live in society: and in this respect, whatever pertains to this inclination belongs to the natural law; for instance, to shun ignorance, to avoid offending those among whom one has to live, and other such things regarding the above inclination"2. So this inclination constitutes a natural impulse to the knowledge of God on the one hand and to the primordial instance to achieve social life by means of justice on the other. That is, justice is the way to social good, ever more so in our globalised world. Of course justice means first and foremost giving each person his due, as the old Latin adage says unicuique suum tribuere ${ }^{3}$. "Each one" is a distributive pronoun, because "the specific act of justice consists in no less than giving to each what is his"4.

“Justice - writes John Rawls at the beginning of 'A Theory of Justice' - is the first prerequisite of social institutions, as truth is of the systems of thought" (Rawls, 1971). This statement seems to be more in agreement with Plato's concept of justice than with Aristotle's. Justice is the virtue of everything in 'The Republic', (Plato) while in the 'Nicomachean Ethics' (Aristotle, 'a') Aristotle considers distributive justice as a special or partial justice with relation to general justice, which is fundamentally respect for the laws of the City. Why a partial virtue? First of all because the equality of distributive justice is not of an arithmetic nature (1=1), as is commutative justice, but of a proportional nature $(2: 4=3: 6)$, i.e., it is an equality of relations between people and goods; i.e. the relation of a person to a good must be analogous to the relation of another person to another good ${ }^{5}$. Moreover, it is partial, because distributive justice deals with the specific situation of the repartition or distribution of goods, honours, advantages. Today we would include, as Rawls states, both commercial goods, i.e. energy, water, food, salaries, property, social benefits, and non commercial ones, i.e. citizenship, security, health, education, honours, including the roles of command, authority, and responsibility carried out within the framework of all kinds of institutions, whether private or public, national or international. Therefore, this is a matter not only of distributing the material goods of the world but also the goods of the spirit, i.e., that which is more specifically human, for, as Aristotle observes, "the human race lives...by art and reasoning" (Aristotle, 'b').

However, why does the Philosopher consider distribution only a part of justice? Probably because he wants to prevent us from thinking of society as a distributor of parts, which is always an act of separation in order to determine which part goes to one and which to the other, when in actual fact society is mainly a whole. Society must be understood as a "cooperation scheme", an expression which we find right from the opening lines of Rawls' 'A Theory of Justice', a book in which, in any case, the analysis of society as a distribution system prevails. Today it is necessary to take into serious consideration a notion of the common good consisting in goods and values that are participated and 
shared by possibly active subjects in the global society. On the other hand, we may see in the metaphor of distribution the two aspects that must be coordinated because in actual fact they belong to each other: repartition is something which divides us because my part is not yours, but at the same time, repartition is something which forces us to share, in the strong sense of the word, be part of, take part in.... Urged by economic worries, today we tend to forget that, unlike material goods, the spiritual goods which are properly human expand and multiply when communicated: i.e., unlike divisible goods, spiritual goods such as knowledge, values and education are indivisible and the more one shares them, the more one possesses of them ${ }^{6}$.

Therefore we can affirm that both for the Greek and for the Medieval thinkers, as well as for contemporary authors, distributive justice is the main virtue of a policy which aims for the common good.

\section{CONCENTRATING ON EDUCATION IS THE FIRST TASK OF A GLOBAL WORLD}

The central reality on which today, more than ever before, we should place emphasis is education. Science - which involves the production, acquisition and transmission of knowledge - and education make up an increasingly interdependent system that shapes life on this planet. The organisation of scientific advance has certainly come to be a much more difficult task than the management of the world's wealth. Education, a specific right of the human being inasmuch as he is a rational being ${ }^{7}$, which should be the most human and effective way to promote freedom, fraternity and social equality, is becoming more and more a factor of discrimination and exclusion. It is well-known that the lack of quality (current values and technology) and quantity (schooling and retention rate) in education is one of the causes of extreme poverty. Today we live in a "knowledge society", that is why it is necessary to extend to everyone and improve the quality of the educational services necessary to take part in it. Indeed, a fair and equitable society distinguishes itself for the level and extent of its education (Pontificia Academia Scientiarum Vatican City, 2002; Suárez-Orozco and Qin-Hilliard, 2004).

Nevertheless, the problem of education in a globalised world does not only mean a problem of distributive justice as regards knowledge, i.e. extending literacy to every inhabitant of the developing countries: the driving forces of globalisation are posing new challenges to education, for families, schools, universities and lifelong training in all the countries of the world, both in developed and developing countries. I would like to stress two aspects that make it necessary to rethink the subject of education in our world, one concerning principally what, in the course of culture, has been defined as the ethical aspect, and the other mainly dealing with the theoretical or anthropological aspect.

\section{THE REHABILITATION OF ETHICS}

Indeed it is important to situate the educational effort within the main consideration of culture, because human beings will not be able to stop questioning themselves on the profound meaning of education with relation to the praxis of the persons, and to direct their attention to the human behaviours centred, after Socrates (470 - 399 b.C.), on the idea of good and virtue. These normative ideas embrace the private and public behaviours that we call "habits" (ethe), which gave origin to the word "ethics", of which good, justice and virtue are ramifications. In its original nucleus, ethics is at the same time a part of the policy concerning human plurality, and the common content of private morals and public morals. This is the reason why ethics is the emblematic end of that activity, which is distinct both from science (epistémé) and from technology. For this reason I would like to quote Aristotle at the beginning of the 'Nicomachean Ethics': “To say however that the Supreme Good is happiness will probably appear a truism; we still require a more explicit account of what constitutes happiness. Perhaps then we may arrive at this by ascertaining what is man's work or deed. For the goodness or efficiency of a flute-player or sculptor or craftsman of any sort, and in general of anybody who has some work or business to perform, is thought to reside in that work; and similarly it may be held that the good of man resides in the work of man, if he carries out a special activity which will permit to discern a fulfilled human life" (Aristotle, 'c').

And such is the issue that specifies this praxis relative to habits, which branches out in ethics and politics. Therefore, the grouping of the praxes concerning habits possesses its own consistence within the framework of the plurality of the human praxis: theoretical praxis, scientific praxis, technical praxis, moral praxis (in the wider sense of habits). The idea of good and fairness constitutes its emblem par excellence. Education should not avoid taking into account the contemporary developments of this idea that are located within that "renaissance of ethics" as a reaction to the "crisis" which this discipline underwent, starting from the second half of the $19^{\text {th }}$ century. Against the descriptive and valueless understanding of human action put in practice by the human and social sciences (in Max Weber's view "without values", value-neutral and ethically neutral) is the need to legitimise and rationally found criteria, norms or principles capable of guiding human action, thus restoring issues such as, for example, the problem of morally good actions, the problem of well living in the private and public framework, the issue of the best type of governance. In the light of this rehabilitation, the first issue of an ethical nature that education must deal with is not so much what must be done but how to teach a conduct of life in order to be happy, that is to live well and be well. 
However, there is more from this ethical point of view. The fact of globalisation is firstly a physical problem which concerns the repercussion of our actions on other people and on our habitat. Today we can observe that what is done in one area has an influence on the others, starting with the environment and passing through the ecosystem. If a city produces pollution, this pollution will slowly spread to the whole world through the natural carriers of air and water. This implies that human health is endangered either directly or through animals that receive the effects of this pollution and transmit their diseases to man. It is clear that all life on this planet is connected and that if we endanger the lives of plants and animals, we also endanger the lives of human beings. What clearly derives from this is that climate, life in general, human life and the economic and cultural activities of man are interconnected, producing no longer just a local effect but a global one. If we want to understand the economy, we must approach it from the interdisciplinary point of view, because it is connected to environmental science and medical science. For this reason, education in a globalised world must take into account not only complexity but also what it is concretely possible to do to improve the life of the present and future generations and implement the results. Today, education must be aware that all individuals, regardless of whether they live in developing countries or in the developed ones, can contribute to either improving or destroying our habitat, the earth and, consequently, the very life of man. Faced with the scenarios of the globalised world we must be able to predict the influence that our actions may have on the future fate of humanity and our planet. This leads to a new imperative which must be proposed in education, which affirms, according to the philosopher Hans Jonas, "Act so that the effects of your action are compatible with the permanence of genuine human life"; or simply: "Do not compromise the conditions for an indefinite continuation of humanity on earth"; or, again turned positive: "In your present choices, include the future wholeness of man among the objects of your will". I must be aware that everyone has the right to an environment that is not harmful to their health or well-being, and to have the environment protected, for the benefit of present and future generations. Nature, we now know, is not inexhaustible and without our stewardship even the most elemental requirements for life are in jeopardy. So, everyone has the right to have the environment protected, through reasonable ethics and legislative and other measures that prevent pollution and ecological degradation, promote conservation, and secure ecologically sustainable development and use of natural resources while promoting justifiable economic and social development. Briefly, today, after globalisation, education must make people aware that what we do makes a difference and each individual can make a difference in the well being and even the survival of our ecosystem, starting from climate and health and passing through family ecology and the other dimensions of human activity ${ }^{8}$.

\section{MAN'S KNOWLEDGE IN THE CONDITION OF SCIENCE}

If the first point aims mainly at practical or ethical reasons, the second one aims particularly at what may be defined as theoretical and anthropological reasons. The globalised world implies an education for all, and not only for the inhabitants of the developed world, that can present in an organic way the tremendous wealth of knowledge that is available today. The idea is that the most important mind in the $21^{\text {st }}$ century will be the mind that can synthesize knowledge, given the explosion of and ready access to it via the new information technologies. Surprisingly, despite the importance that offering a synthesized or summarised vision of the world has always had, such as was the case in the past (Aristotle, Augustine, Aquinas, Kant), there has been little systematic research on this skill in the present. So the aim of education from now on should be to teach the capacity of synthesizing today's knowledge and how to continue to develop this dynamic vision in order to keep up to date with the new realities (Gardner, 2005).

It is also the case of offering a hierarchy of knowledge where certain truths are the foundation that others are built upon. Perhaps the first thing that must be clear in a globalised education is our knowledge of the human being in the condition of science.

There was no greater problem until a border was traced between nature intended as possessing a soul or as surrounded by a soul, and a soul which was in itself characterised by an end: this is the epoch of Aristotelian physics and natural ethics. This border was traced at the end of the Renaissance.

The problem became serious when nature became the object of a science based on pure observation, mathematical calculations and experimentation. This is the meaning of the Galileian and Newtonian revolution, as Kant (1787) defined it. The human spirit considers it has no access to the principle of the production of nature in itself or for something other than itself, what Aristotle calls form or formal principle as principle of operation. Therefore only the natural gifts made known in their appearance in space and time can be gathered and phenomena must try to "be saved". This is no small feat, since the field of observation is so limitless while so powerful is the capability of forming hypotheses with a mathematical formula, of extending and replacing models, of varying the creation of models, of inventing verification and falsification procedures.

However, with the phenomena relative to the human being, this asceticism of the hypothesis, of the creation of models and of experimentation is in part compensated by the fact that we have partial access to the production of certain phenomena which are observable through philosophical self-reflection. This is what, in the praxis of that scientific theory, technologies and habits, can be designated as that genetics of action which belongs to philosophic 
anthropology. The reflection on the praxes expresses the point of convergence because it indicates the means to an end, that is, human deeds carried out as fulfilment of the human act. Action shows that man moves towards a goal and that he himself is the beginning and the motor of the action. In the vast field of activity, the human being considers himself responsible for his own action. This means that he can trace back the observable effects of his actions (and of his passions) to the intention that gives them meaning and even to the spiritual acts which create finalities that generate observable intentions and results. Thus action can not only be viewed from the outside, like all the natural phenomena of which it is part, but it can also be understood starting from the expressions which are, at the same time, the effects and signs of the intentions that give meaning to it and to the acts creators of meaning which sometimes produce them. The result is that man's knowledge does not happen at a single level, that of external observation, explanation and experimentation (as a reproduction of phenomena); this knowledge unfolds in the interface of natural observation and of reflective selfcomprehension. The human being is at the same time an observable entity, like all the natural beings of which he is a part, and a self-interpreting being, according to Charles Taylor.

This affirmation of the various objective levels of epistemology and, first of all, of the different levels of awareness and self-awareness of the human being, can offer an answer of reconciliation and pacification to the question posed by the statute of the human being in the field of knowledge, unless positivist ideology does not claim the right to abolish the border between the sciences of nature and the sciences of man and to annex the latter to the former.

A controversial point to this end is the field of the neurosciences, which today more than ever are decisive for education. Of course I will limit myself to tracing only the conditions of a possible articulation of the two approaches to man.

In terms of the neurosciences, the scientist is expected to seek at the cortical level the correlation between the observable structures and the functions where the structures are the basis, the supports, the nervous material or whatever we may want to call it. The scientist only observes quantitative and qualitative changes, the ever more complex hierarchies of observable phenomena; but the sense of the function which corresponds to the structure is understood only by the subject who says that he perceives, that he imagines, that he recalls. These verbal statements, together with behavioural signs that the human being shares to a large extent with higher animals, fall within a type of approach where there is no mention of neurons, synapses etc. but of impressions, intentions, dispositions, wishes, choices, ideas etc. We find here a certain semantic dualism, if we may say so, that does not jeopardise the absolute nature of the human being. An important corollary of such semantic dualism consists in the fact that we speak in similar terms of the body, of the same body in both approaches: there is the body object, of which the brain is the guiding force with its marvellous architecture, and the body proper, this body that is the only one that is mine, that belongs to me, which I move, which I suffer; and there are my organs, my eyes "with" which I see, my hands "with" which I grasp. And it is on this body proper that all the architecture of my powers and my non-powers is built: power to do and not to do; power to do this or that; power to say, to act, to attribute to myself my own actions as the real author of them, being therefore free.

So this is where the issue of the relationship between the two approaches, that of the neurologist and that of the philosopher or humanist, emerges. And it is here that the approaches cross without ever dissolving one into the other. The scientist and the philosopher can agree to call the body object (and its marvel, the brain), the "reality without which we cannot think or decide or feel or live". The scientist can continue to profess a sort of materialism in his method, which enables him to work without metaphysical scruples: the philosopher therefore will speak of the brain in terms of recipient structure, of support, of substrate, of basis, of potency, of encephalic matter. It must be accepted that, for the moment, we do not have a third approach where there appears a certain awareness that this mind-body and my living body are one and the same being. However, the approach of this mind-body must have a certain opening towards the approach of my living body and vice versa, and that is while the approach of my living body gives to me my experience and philosophical reflection, it must be open or enable indirectly or per accidents the approach of this mind-body and vice versa.

We notice here that we do not have direct access to the very origin of the being that we are, in other words we do not have a sort of self-transparency of ourselves and of our selfhood and, starting from this centre, a self-transparency also of all of our actions. On the contrary, our being attests its existence in the concrete and current exercise of our life. In a realist vision, Saint Thomas indicates it clearly: "In hoc enim aliquis percepit se animam habere, et vivere et esse, quod percepit se sentire et intelligere et alia huiusmodi opera vitae exercere” (Saint Thomas Aquinas, 'a'). In the perception of our praxis or activity there is the coperception of the beginning: "perceptis actibus animae, percipitur inesse principium talium actum" (Saint Thomas Aquinas, 'b'). Saint Thomas assures us that our soul, since it grasps universals, perceives (percepit) that is has a spiritual form; again, he admits that we are aware of the very becoming of the universal in the soul and even that the very light of intelligence makes its presence known to us by means of it. This signifies affirming in an explicit manner a perception proper of the spiritual reality in a positive way but by means of the spiritual operation of implementing the intelligible: "And we know this by experience, since we perceive that we abstract universal forms from their particular conditions, which is to make them actually 
intelligible" i.e. "Et hoc experimento cognoscimus, dum percimus nos abstrahere formas universales a conditionibus particularibus quod est facere actu intelligibilia”?

The ultimate originality of this perception of our spiritual reality is the absolutely original fundamental situation that we may call "the emergence of freedom" or of the capability of acting or of non acting, of doing good or evil. Quite rightly Christian thought, long before and with more precision than the moderns, regarding this reality of the spiritual subject, had called freedom the "motor omnium" of the activity of the person, and the protagonist of personality is the "I", the self (selfhood), the human subject that we discover through praxis. Therefore the soul lies hidden within each of us, but it attests its presence with the capability of action, then with praxis and agency itself, of which the self, selfhood or the original subject is the beginning, the motor and the end. This attestation is more than an opinion and is older than any science, both theoretical and practical.

Aware of the lack of a direct and self-transparent approach of such a founding origin, scientists and philosophers will aim at seeking an ever more precise adjustment between a neuroscience which is more and more expert in material architecture and the phenomenological and anthropologic descriptions "decentred" towards an origin, thanks to which a ground of being is indicated, at once potent and effective, against which human acting stands out. In other words, it appears equally important that human acting is the locus of legibility par excellence both of naturalistic neuroscience and of the anthropological reflection and that the being as act and as potency has fields of application other than human action. Neuronal and philosophical centrality in acting and decentring in the direction of a ground of act and potency, these two traits are equally and jointly constitutive of an ontology of the human being in terms of act and potency (Ricoeur, 1992). Therefore only the human being has this double legibility, the external objective one that is common to all the beings of nature that is the theme of epistémé and the one of self-reflection which belongs to philosophy according to the Socratic precept "know yourself" which understands its being as an act of an active potency that we call soul (Saint Thomas Aquinas, 'c'). Therefore, only the human being is able to create a circularity between one and the other legibility, seeing, so to speak, externally the functioning of his brain with the new sensors that represent it as in a film and interpreting from the inside this representation in the film starting from self-reflection on himself.

There is nothing more ours than our brain yet there is nothing we know less about. The ancients thought that the heart was the centre of life because it beats constantly like a pump telling us "I am here". On the contrary, the brain was, so to speak, the big silence, the great silence or the sealed box of our body. Today however the brain opens up and shows itself in part thanks to the neurosciences and it can prove to be the turning point for a new beginning where the external experience can be joined to the internal one and science can be joined with philosophy each in its respective function and consistency, and in their mutual circularity. In this way a breach can be achieved in the limit of encephalic matter, that keeps conscience always on the alert and in motion. This is not present in the ancient philosophies, in the Middle Ages, in the modern or in the contemporary ones, and if the human being is analysed, he is so from a formal point of view without these dynamic and circular links with scientific knowledge of my body and my brain. This starts being true in those sciences, such as neurology, that are starting to open up to other fields of knowledge. It is not that I am my body, not even its masterpiece which is the brain: I am neither the brain nor the body, I have a brain and a body but - as we have tried to show - in order to understand my "being" I must know what it means to have a brain, to have a body through the knowledge of them that experience and science offer to me.

This knowledge of man starting from the genetics of action that takes into account the data offered by neurological science can prove to be the decisive moment for a new beginning also for education as shown by the new discipline that tries to put together both the mind-brain issue and the recent research in education which is rightly called mind-brain education. Therefore, education today cannot ignore science and philosophy or this new interdisciplinary point of view on man, the mind-brain education that can clarify the question of the truth of the human being and his dignity. The explanation of the concept of human dignity in education, that is, the fundament of the modern human rights theory, cannot be overemphasised or taken for granted.

\section{REFERENCES}

ARISTOTLE, 'a'. Nicomachean Ethics, Book V. Available from Internet: http://etext.library.adelaide.edu.au/a/aristotle/nicomachean/ book5.html.

ARISTOTLE, 'b'. Metaphysics, Book I. Available from Internet:

http://etext.library.adelaide.edu.au/a/aristotle/metaphysics/b ook1.html.

ARISTOTLE, 'c'. Nicomachean Ethics. Available from Internet:

http://etext.library.adelaide.edu.au/a/aristotle/nicomachean/ complete.html.

GARDNER, H. The Synthesizing of Knowledge: An Imperative in a Global Society. Abstract for the workshop on 'Globalisation and Education' to be held in November, Vatican City 2005.

KANT, Immanuel. Critique of Pure Reason. Preface to the second edition (1787). Available from Internet: http://etext.library.adelaide.edu.au/k/kant/immanuel/k16p/k 
16p2.html.

KHOR, Martin. Globalisation and the South: Some Critical Issues. Penang, Malaysia, Third World Network, 2000. 110 p. ISBN 983-9747-46-0.

Le Figaro économique, June $2^{\text {nd }}$, 2004, p. III.

PLATO. The Republic, Book IV. Available from Internet: http://etext.library.adelaide.edu.au/p/p71r/book04.html.

PONTIFICIA ACADEMIA SCIENTIARUM VATICAN CITY. The Challenges for Science. Education for the Twenty-First Century, Vatican City 2002, pp. VII-292. ISBN 88-7761-080-8. Available from Internet: http://www.vatican.va/roman_curia/pontifical_academies/a cdscien/archivio/s.v.104_the_challenges/part1.pdf.

RAWLS, John. A Theory of Justice. The Belknap of Harvard University Press, Cambridge, MA, USA, 1971.

RICOEUR, Paul. Tenth Study: What Ontology in View?. In: Oneself as Another. Chicago-London, 1992, pp. 302308. ISBN 0226713296.

SAINT THOMAS AQUINAS, 'a'. Quaestiones disputatae: De Veritate. 10, 8.

SAINT THOMAS AQUINAS, 'b'. Quaestiones disputatae: De Veritate. 10, 9.

SAINT THOMAS AQUINAS, 'c'. Quaestiones disputatae: Quaestiones disputatae de spiritualibus creaturis. A. 1.

SUÁREZ-OROZCO, Marcelo and QIN-HILLIARD, Desiree B. eds. Globalization, Culture and Education in the New Millennium', University of California, Berkeley, Los Angeles-London, 2004, 275 p.

The Pontifical Academy of Sciences. Address to the Pontifical Academy of Sciences, 12 November 1983, Papal Addresses, Vatican City, 2003, p. 261.

UNDP Report 1999 (United Nations Development Programme). Human Development Report 1999. Globalization with a Human Face. 1999. Available from Internet: http://hdr.undp.org/reports/global/1999/en/.

UNDP Report 2003 (United Nations Development Programme). Human Development Report 2003. Millennium Development Goals: A compact among nations to end human poverty. 2003. Available from Internet: http://hdr.undp.org/reports/global/2003/.

\footnotetext{
${ }^{1}$ Saint Thomas Aquinas places great emphasis on the superior architectural importance of justice inasmuch as it orders each man, in himself and in relation to others, to good: "Pars autem id quod est totius est, unde et quodlibet bonum partis est ordinabile in bonum totius. Secundum hoc
}

igitur bonum cuiuslibet virtutis, sive ordinantis aliquem hominem ad seipsum sive ordinantis ipsum ad aliquas alias personas singulares, est referibile ad bonum commune, ad quod ordinat iustitia. Et secundum hoc actus omnium virtutum possunt ad iustitiam pertinere, secundum quod ordinat hominem ad bonum commune. Et quantum ad hoc iustitia dicitur virtus generalis", i.e. "... while a part, as such, belongs to a whole, so that whatever is the good of a part can be directed to the good of the whole. It follows therefore that the good of any virtue, whether such virtue direct man in relation to himself, or in relation to certain other individual persons, is referable to the common good, to which justice directs: so that all acts of virtue can pertain to justice, in so far as it directs man to the common good. It is in this sense that justice is called a general virtue". (S. Th., II-II, q. 58, a. 5 cor.). The comparison with charity is also very meaningful. "Sicut enim caritas potest dici virtus generalis inquantum ordinat actus omnium virtutum ad bonum divinum, ita etiam iustitia legalis inquantum ordinat actus omnium virtutum ad bonum commune. Sicut ergo caritas, quae respicit bonum divinum ut proprium obiectum, est quaedam specialis virtus secundum suam essentiam; ita etiam iustitia legalis est specialis virtus secundum suam essentiam, secundum quod respicit commune bonum ut proprium obiectum. Et sic est in principe principaliter, et quasi architectonice; in subditis autem secundario et quasi ministrative" (Ib., a. 6 cor.).

2 "Inest homini inclinatio ad bonum secundum naturam rationis, quae est sibi propria, sicut homo habet naturalem inclinationem ad hoc quod veritatem cognoscat de Deo, et ad hoc quod in societate vivat. Et secundum hoc, ad legem naturalem pertinent ea quae ad huiusmodi inclinationem spectant, utpote quod homo ignorantiam vitet, quod alios non offendat cum quibus debet conversari, et cetera huiusmodi quae ad hoc spectant" (S. Th., I-II, q. 94, a. 2 cor.).

${ }^{3}$ Saint Ambrose affirms that: "iustitia est quae unicuique quod suum est tribuit, alienum non vindicat, utilitatem propriam negligit ut communem aequitatem custodiat", i.e. "It is justice that renders to each one what is his, and claims not another's property; it disregards its own profit in order to preserve the common equity." (De Off. 1, 24).

4 "Proprius actus iustitiae nihil est aliud quam reddere unicuique quod suum est" (S. Th., II-II, q. 58, a. 11 cor.).

5 "Generalis forma iustitiae est aequalitas, in qua convenit iustitia distributiva cum commutativa. In una tamen invenitur aequalitas secundum proportionalitatem geometricam, in alia secundum arithmeticam", i.e. "Equality is the general form of justice, wherein distributive and commutative justice agree: but in one we find equality of geometrical proportion, whereas in the other we find equality of arithmetical proportion". (S. Th., II-II, q. 61, a. 2 ad 2).

6 "Spiritualia bona sunt specialiter non ritenenda per se, quia comunicata non minuuntur sed crescent" (St. Thomas Aquinas, De Malo, q. 13, 1 pret. 8).

7 "All men of every race, condition and age, since they enjoy the dignity of a human being, have an inalienable right to an education" (Vatican Council II, Declaration on Christian Education, Gravissimum Educationis, § 1). Cfr. Pius XII's 
radio message of Dec. 24, 1942, A.A.S. 35 (1943), pp. 1219; and John XXIII's encyclical letter, Pacem in Terris, 11 April 1963, A.A.S. 55 (1963), p. 259 ff. Also, cfr. Declaration on the Rights of Man, in footnote 3.

${ }^{8}$ We find here the problem of the responsibility that each person has of the effects of his actions, especially when these effects are negative and involuntary. The following text of Saint Thomas Aquinas may serve to clarify the problem: "a judge has a good will, in willing a thief to be put to death, because this is just: while the will of another--e.g. the thief's wife or son, who wishes him not to be put to death, inasmuch as killing is a natural evil, is also good [...] because the judge has care of the common good, which is justice, and therefore he wishes the thief's death, which has the aspect of good in relation to the common estate; whereas the thief's wife has to consider the private, the good of the family, and from this point of view she wishes her husband, the thief, not to be put to death" (S. Th., I-II, $19,10)$. So, the alternative to total and indiscriminate responsibility is the graduation according to the order of relation that each has with the common good, of course to the extent to which each seeks the good not by doing evil deeds.

${ }^{9}$ S. Th., I, 79, 4. Also: "The human soul understands itself through its own act of understanding, which is proper to it, showing perfectly its power and nature" i.e. "Anima humana intelligit seipsam per suum intelligere, quod est actus proprius eius, perfecte demonstrans virtutem eius et naturam" (Ib. I, 88, 2 ad 3). 